\title{
Siew New Disease Reports \\ First report of Iris yellow spot virus in onion in Tajikistan
}

\author{
O.J. Alabi ${ }^{1}$, N. Saidov ${ }^{2}$, R. Muniappan ${ }^{3}$ and R.A. Naidu ${ }^{1 *}$ \\ ${ }^{1}$ Department of Plant Pathology, Washington State University Irrigated Agriculture Research and Extension Center, 24106 \\ N. Bunn Rd., Prosser, WA 99350; ${ }^{2}$ Research Fellow, IPM CRSP project, Post Box 70, 734025, Dushanbe, Tajikistan; ${ }^{3}$ \\ Program Director, IPM CRSP, Virginia Tech, Blacksburg, VA 24061 \\ *E-mail: naidu.rayapati@wsu.edu
}

Received: 07 Sep 2012. Published: 09 Dec 2012. Keywords: Allium cepa, thrips

The bulb onion (Allium cepa) is an important crop for farmers' income and overall economy and food security of Tajikistan. During a limited survey of onion fields near Dushanbe in June 2011, we observed onion plants showing characteristic diamond-shaped lesions (with or without green islands) on leaves and scapes (Fig. 1). Since these symptoms are characteristic of Iris yellow spot virus (IYSV), a thrips-transmitted virus belonging to the genus Tospovirus in the family Bunyaviridae (Gent et al. 2006), leaf samples were imprinted on FTA $^{\circledR}$ Classic Cards (Whatman International Ltd., Maidstone, UK), air-dried and brought to the laboratory at Washington State University for confirmatory diagnostic tests. Viral nucleic acids were eluted from five FTA cards (Alabi et al., 2008) representing five separate onion samples and subjected to reverse transcription (RT)-PCR using primers (IYSV56U and IYSV917L) flanking the nucleocapsid protein (NP) gene of IYSV (Robène-Soustrade et al., 2006. A single DNA product of approximately 896 base pairs (bp) was amplified from all samples. The 896 bp DNA fragments were cloned separately into pCR2.1 (Invitrogen Corp., Carlsbad, CA) and two independent clones per amplicon were sequenced in both orientations. In pairwise comparisons, complete NP gene coding sequences of isolates from Tajikistan (GenBank Accessions Nos. JQ814625 to JQ814630) showed 99-100\% nucleotide (nt) identities among themselves and 87-98\% nt identities with corresponding NP gene sequences of global IYSV isolates. Maximum likelihood phylogenetic analysis revealed that IYSV isolates from Tajikistan are more closely related to isolates from Serbia (EU586203, EU750697) and Italy (FJ185142) with $>70 \%$ bootstrap support (1000 replicates; Fig. 2). Thrips tabaci was observed in onion flowers. To our knowledge, this is the first confirmed report of IYSV in onions in Tajikistan. In recent years, IYSV has been reported in many onion-growing regions and our finding of its occurrence in Central Asia, considered as the centre of origin for onion, expands our knowledge of global distribution of IYSV.



Figure 1

Figure 2

\section{Acknowledgements}

The authors would like to thank Elisa Cantu and Jessica Miklas for their technical assistance. This research was supported by the Agriculture Office within the Bureau for Economic Growth, Agriculture, and Trade of the US Agency for International Development (USAID), under the terms of the Integrated Pest Management Collaborative Research Support Program Cooperative Agreement No. EPP-A-00-04-00016-00. Opinions expressed herein are those of the authors and do not necessarily reflect the views of USAID.

\section{References}

Gent DH, du Toit LJ, Fichtner SF, Mohan SK, Pappu HR, Schwartz HF, 2006. Iris yellow spot virus: An emerging threat to onion bulb and seed production. Plant Disease 90, 1468-1480. [http://dx.doi.org/10.1094/PD-90-1468

Alabi OJ, Kumar PL, Naidu RA, 2008. Multiplex PCR method for the detection of African cassava mosaic virusand East African cassava mosaic Cameroon virusin cassava. Journal of Virological Methods 154, 111-120. [http://dx.doi.org/10.1016/j.jviromet.2008.08.008]

Robène-Soustrade I, Hostachy B, Roux-Cuvelier M, Minatchy J, Hédont M, Pallas R, Couteau A, Cassam N, Wuster G, 2006. First report of Iris yellow spot virus in onion bulb- and seed-production fields in Réunion Island. Plant Pathology 55, 288

[http://dx.doi.org/10.1111/j.1365-3059.2005.01262.x]

Tamura K, Peterson D, Peterson N, Stecher G, Nei M, Kumar S, 2011. MEGA5: Molecular evolutionary genetics analysis using maximum likelihood, evolutionary distance, and maximum parsimony methods. Molecular Biology and Evolution 28, 2731-2739

[http://dx.doi.org/10.1093/molbev/msr121]

To cite this report: Alabi OJ, Saidov N, Muniappan R, Naidu RA, 2012. First report of Iris yellow spot virus in onion in Tajikistan. New Disease Reports 26, 28. [http://dx.doi.org/10.5197/j.2044-0588.2012.026.028] 